\title{
FOUR TREMOLITES FROM CARBONATE ROCKS OF FINLAND
}

\author{
KAI HYTÖNEN and PENTTI OJANPERÄ
}

\begin{abstract}
HYTÖNEN, KAI and OJANPERÄ, PENTTI 1976: Four tremolites from carbonate rocks of Finland. Bull. Geol. Soc. Finland 48, 63-69.

Chemical composition and physical properties are given for four tremolites from Precambrian metamorphic carbonate rocks and skarns of Eastern and Northern Finland. The relation between the unit cell volume and the composition has been illustrated by means of a diagram.

Kai Hytönen and Pentti Ojanperä, Geological Survey of Finland, SF-02150 Espoo 15, Finland.
\end{abstract}

\section{Introduction}

Amphiboles of the tremolite-actinolite series are important constituents of the Finnish Precambrian metamorphic carbonate rocks and skarns. They are especially common in Eastern and Northern Finland. From a few localities in Eastern Finland detailed descriptions of tremolites from skarns and related rocks have been published (e.g. Frosterus and Wilkman 1916; Haapala 1936; Vähätalo 1953). In addition, analyses and physical data are available also for tremolite-actinolites from a soapstone (Wiik 1953), calcareous black schist (Peltola 1960) an amphibole-epidote-albite-rock (Meriläinen 1961), a tremolite-phlogopite rock (Nuutilainen 1968) and a syenite (Puustinen 1972).

Quartz, tremolite, diopside and wollastonite are regarded as characteristic accessory minerals in the classification of the limestones of Finland (Eskola 1919). These accessory min- erals have been used as indicators of the metamorphic habit of the limestones and a regional distribution of the limestones on the basis of this classification has been presented by Aurola (1960). Tremolite-limestones are typically found in Eastern and Northern Finland. Three of the tremolites described in this paper (Fig. 1. specimens No. 2, 3, 4) are from the tremolite-limestone "region", one (specimen No. 1) is from the diopside-limestone $»$ region».

Of the authors, Hytönen is responsible for the physical data and the writing, Ojanperä for the chemical analyses.

\section{Materials}

The locations of the four tremolite specimens are shown in the map, Figure 1. In the following, short descriptions are given of the rocks and the localities: 


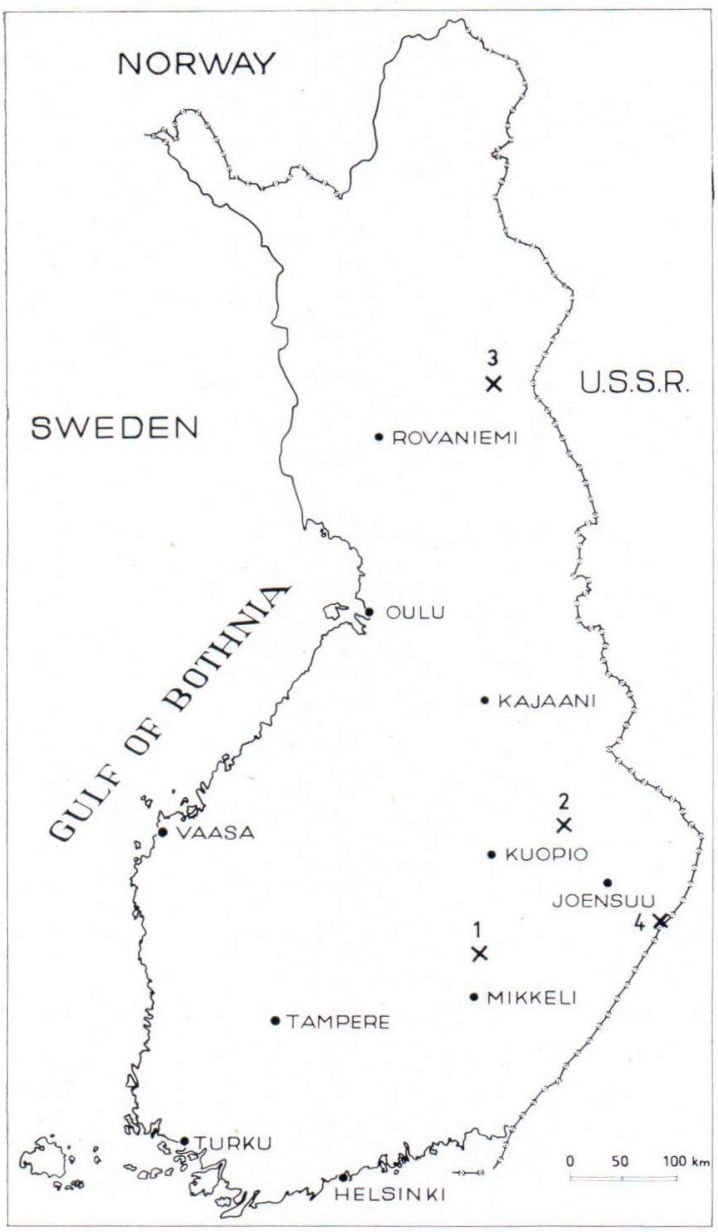

Fig. 1. Map of Finland showing the locations of the tremolites studied: 1. Virtasalmi; 2. Juuka; 3. Salla; 4. Värtsilä.

Specimen 1. Calcite-tremolite-diopside rock, with white, radiating fibers of tremolite, measuring up to $2 \mathrm{~cm}$ in length. From the limestone quarry of Ankele (owned by the firm Paraisten Kalkkivuori Osakeyhtiö Pargas Kalkbergs Aktiebolag) in Virtasalmi commune. The locality is shown on a geological map published by Hyvärinen (1969).

Specimen 2. Dolomite-tremolite rock with a little calcite. Tremolite occurs as greenish, radiating fibres, sometimes slightly bended, and measures up to $1-2 \mathrm{~cm}$ in length. From
Kajoo, Juuka commune. Outcrop along the Tuusniemi-Juuka road. Map sheet 4311 (Huhma 1971).

Specimen 3. Dolomite-tremolite rock with a little brown mica. Tremolite occurs as light greenish or greyish tabular, prismatic crystals, measuring $1-2 \mathrm{~cm}$ in length, and contains abundant dolomite inclusions, sometimes as parallel lines. Outcrop c. $3 \mathrm{~km}$ northwest of Pahkakumpu, Salla commune. Map sheet 3643 (Lauerma 1967).

Specimen 4. Calcite-tremolite rock with some pale brown mica. Tremolite occurs as greyish green, tabular prisms, measures up to $5-10 \mathrm{~mm}$ in length and contains calcite inclusions. From a vein-like inclusion in arkosite, near Onkilampi, Värtsilä commune. Map sheet $4232+4234$ (Nykänen 1967, 1968).

\section{Chemistry}

Due to inclusions the tremolites were ground to a powder of $<0.15 \mathrm{~mm}$ and purified with heavy liquids in a centrifuge and, when necessary, with a Frantz-type isodynamic separator. The purities of the samples to be analyzed were checked by microscopic examination: foreign grains and inclusions total up to c. 0.1 percent in the samples 2 and 4 , up to c. 0.3 percent in sample 1 and up to ca. 0.5 percent (mainly dolomite inclusions) in sample 3 .

The results of the chemical analyses, the numbers of the main ions on the basis of 24 $(\mathrm{O}, \mathrm{OH}, \mathrm{F}, \mathrm{Cl})$ and the ratios $100 \mathrm{Mg}:(\mathrm{Mg}+$ $\mathrm{Fe}^{2+}+\mathrm{Fe}^{3+}+\mathrm{Mn}$ ) are presented in Table 1. Of the oxides and elements listed, $\mathrm{SiO}_{2}$, $\mathrm{Al}_{2} \mathrm{O}_{3}, \mathrm{Fe}_{2} \mathrm{O}_{3}, \mathrm{FeO}, \mathrm{MnO}, \mathrm{MgO}, \mathrm{CaO}, \mathrm{Na}_{2} \mathrm{O}$, $\mathrm{K}_{2} \mathrm{O}, \mathrm{P}_{2} \mathrm{O}_{5}, \mathrm{CO}_{2}, \mathrm{H}_{2} \mathrm{O}, \mathrm{F}$ and $\mathrm{Cl}$ were determined by the wet chemical method, $\mathrm{Ti}, \mathrm{Cr}$, $\mathrm{V}, \mathrm{Ni}$ and $\mathrm{Co}$ by optical spectrometry and $\mathrm{ZrO}_{2}, \mathrm{SrO}$ and $\mathrm{BaO}$ by X-Ray fluorescence.

In the conventional terminology all four are tremolites. No. 1 has a composition quite 
Table 1. Chemical analyses, numbers of the main ions of the basis of $24(\mathrm{O}, \mathrm{OH}, \mathrm{F}, \mathrm{Cl})$, and some physical data for four tremolites of Finland.

\begin{tabular}{|c|c|c|c|c|}
\hline & $\begin{array}{c}1 \\
\text { Virta- } \\
\text { salmi }\end{array}$ & $\begin{array}{c}2 \\
\text { Juuka }\end{array}$ & $\begin{array}{c}3 \\
\text { Salla }\end{array}$ & $\begin{array}{c}4 \\
\text { Värtsilä }\end{array}$ \\
\hline $\begin{array}{l}\mathrm{SiO}_{2} \\
\mathrm{TiO}_{2} \\
\mathrm{ZrO}_{2} * * \\
\mathrm{Al}_{2} \mathrm{O}_{3} \\
\mathrm{Fe}_{2} \mathrm{O}_{3} \\
\mathrm{FeO} \\
\mathrm{MnO} \\
\mathrm{MgO} \\
\mathrm{CaO} \\
\mathrm{BaO} * * \\
\mathrm{SrO}_{*} * \\
\mathrm{Na}_{2} \mathrm{O} \\
\mathrm{K}_{2} \mathrm{O} \\
\mathrm{P}_{2} \mathrm{O}_{5} \\
\mathrm{CO}_{2} \\
\mathrm{H}_{2} \mathrm{O}+ \\
\mathrm{H}_{2} \mathrm{O}- \\
\mathrm{F} \\
\mathrm{Cl} \\
\mathrm{Cr} * \\
\mathrm{~V} * \\
\mathrm{Ni}^{*} \\
\mathrm{Co} *\end{array}$ & $\begin{array}{c}58.94 \\
* * * \\
0.00 \\
0.14 \\
0.04 \\
0.29 \\
0.00 \\
24.86 \\
13.50 \\
0.00 \\
0.00 \\
0.04 \\
0.02 \\
0.02 \\
0.00 \\
2.12 \\
0.04 \\
0.06 \\
0.01 \\
<\quad 0.001 \\
<.001 \\
<0.001 \\
<\quad 0.001\end{array}$ & $\begin{array}{c}58.32 \\
0.02 * \\
0.00 \\
0.53 \\
0.40 \\
1.33 \\
0.15 \\
23.96 \\
13.27 \\
0.00 \\
0.00 \\
0.05 \\
0.02 \\
0.01 \\
0.00 \\
2.08 \\
0.04 \\
0.04 \\
0.01 \\
<.001 \\
<.001 \\
<.001 \\
0.001\end{array}$ & $\begin{array}{c}55.37 \\
0.08 * \\
0.00 \\
3.50 \\
1.66 \\
0.06 \\
0.01 \\
23.28 \\
13.63 \\
0.00 \\
0.00 \\
0.21 \\
0.10 \\
0.06 \\
0.16 \\
2.00 \\
0.04 \\
0.07 \\
0.02 \\
0.009 \\
0.001 \\
<.001 \\
0.002\end{array}$ & $\begin{array}{c}56.84 \\
0.05 * \\
0.00 \\
1.21 \\
1.33 \\
3.25 \\
0.24 \\
21.98 \\
13.14 \\
0.00 \\
0.00 \\
0.12 \\
0.03 \\
0.02 \\
2.06 \\
0.02 \\
0.06 \\
0.02 \\
0.005 \\
0.001 \\
0.001 \\
0.002\end{array}$ \\
\hline$-\mathrm{O}=\mathrm{F}, \mathrm{Cl}$ & $\begin{array}{r}100.08 \\
0.03 \\
100.05\end{array}$ & $\begin{array}{r}100.23 \\
0.02 \\
100.21\end{array}$ & $\begin{array}{r}100.25 \\
0.03 \\
100.22\end{array}$ & $\begin{array}{r}100.37 \\
0.03 \\
100.34\end{array}$ \\
\hline $\begin{array}{l}\mathrm{Si} \\
\mathrm{Al} \\
\mathrm{Al} \\
\mathrm{Ti} \\
\mathrm{Fe}^{3+} \\
\mathrm{Fe}^{2+} \\
\mathrm{Mn} \\
\mathrm{Mg} \\
\mathrm{Ca} \\
\mathrm{Na} \\
\mathrm{K} \\
\mathrm{OH} \\
\mathrm{F}+\mathrm{Cl}\end{array}$ & $\begin{array}{l}\left.\begin{array}{l}7.98 \\
0.02 \\
-\end{array}\right\} 8.00 \\
- \\
\begin{array}{c}0.03 \\
-\end{array} \\
\left.\begin{array}{l}5.03 \\
1.96 \\
0.01 \\
-\end{array}\right\} 1.06 \\
\left.\begin{array}{l}1.92 \\
0.03\end{array}\right\} 1.95\end{array}$ & 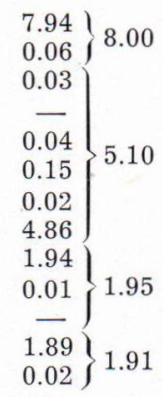 & 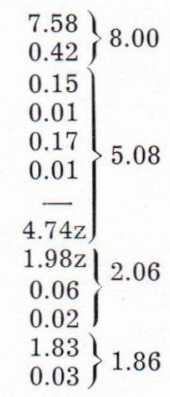 & $\left.\begin{array}{l}7.83 \\
0.17 \\
0.03 \\
0.01 \\
0.14 \\
0.37 \\
0.03 \\
4.50\end{array}\right\} 5.00$ \\
\hline $\begin{array}{l}100 \mathrm{Mg}:(\mathrm{Mg}+ \\
\left.\mathrm{Fe}^{2}++\mathrm{Fe}^{3}++\mathrm{Mn}\right)\end{array}$ & 99.3 & 95.9 & 96.4 & 89.3 \\
\hline $\begin{array}{l}\text { Density: } \\
\text { measured values }\end{array}$ & $\begin{array}{l}2.976 \\
2.980\end{array}$ & $\begin{array}{l}2.997 \\
3.001\end{array}$ & $\begin{array}{l}2.995 \\
2.999\end{array}$ & $\begin{array}{l}3.019 \\
3.024\end{array}$ \\
\hline $\begin{array}{l}\text { average } \\
\text { calculated }\end{array}$ & $\begin{array}{l}2.978 \\
2.965\end{array}$ & $\begin{array}{l}2.999 \\
2.981\end{array}$ & $\begin{array}{l}2.997 \\
3.000\end{array}$ & $\begin{array}{l}3.022 \\
3.016\end{array}$ \\
\hline
\end{tabular}


Table 1 continued

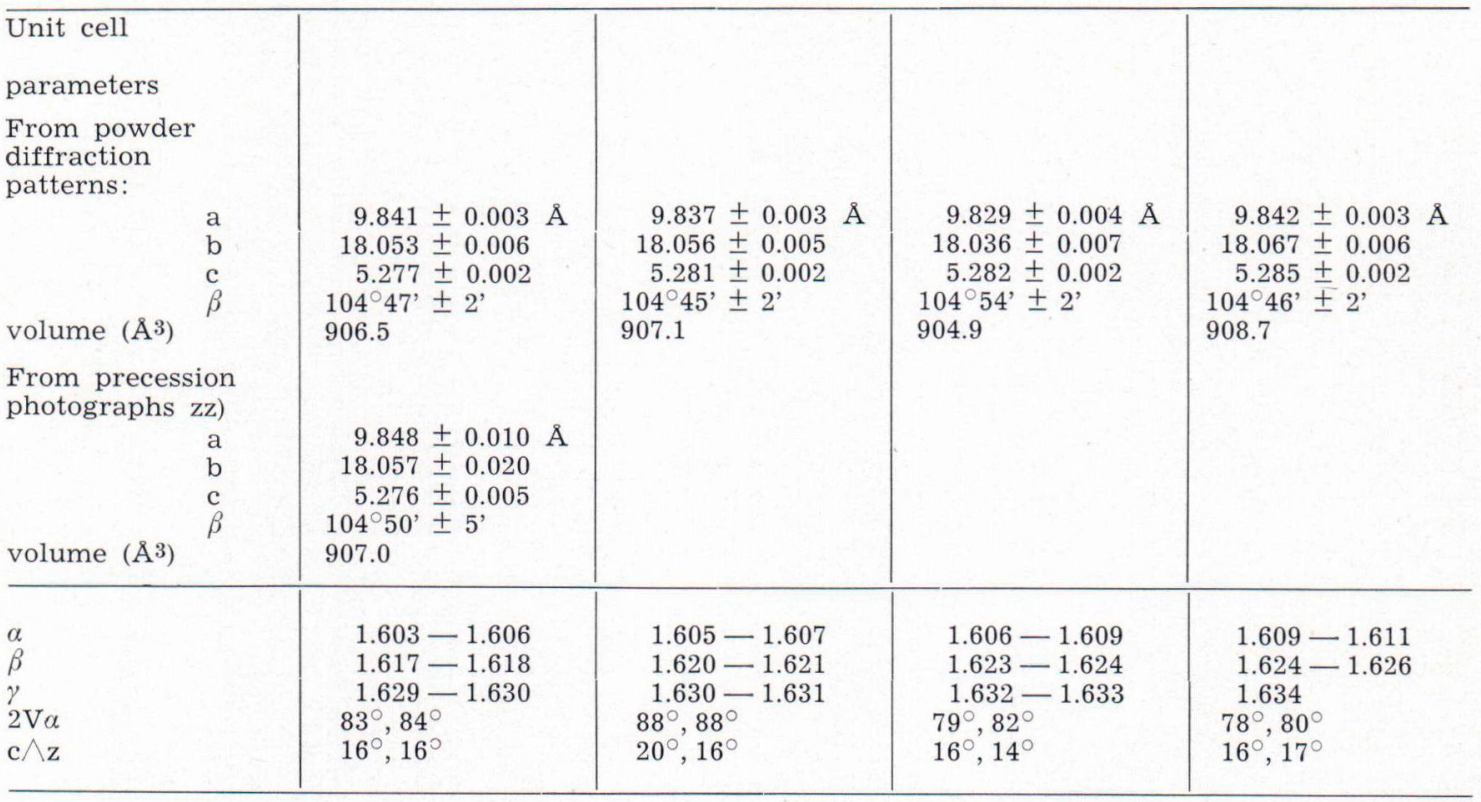

* Optical spectrometric analyses by A. Löfgren. The figures for $\mathrm{Cr}, \mathrm{V}$, Ni and Co have not been included with the totals of the analyses.

** X-Ray fluorescence analyses by V. Hoffrén.

*** Optical spectrometric analysis by A. Löfgren gave $\mathrm{Ti}<0.01 \%$.

$\mathrm{z}$ Corrected for dolomite, calculated on the basis of 0.16 percent $\mathrm{CO}_{2}$ in the analysis.

zz By Atso Vorma

close to the pure end member, $\mathrm{Ca}_{2} \mathrm{Mg}_{5} \mathrm{Si}_{8} \mathrm{O}_{22}$ $(\mathrm{OH})_{2}$. No. 3 with 3.5 percent $\mathrm{Al}_{2} \mathrm{O}_{3}$ strives towards the hornblende series and its ferric to ferrous iron ratio is unusual.

Examination of the analyses reveals a positive correlation between the amounts of $\mathrm{TiO}_{2}$, $\mathrm{Al}_{2} \mathrm{O}_{3}, \quad \mathrm{Fe}_{2} \mathrm{O}_{3}, \quad \mathrm{Na}_{2} \mathrm{O}$ and $\mathrm{K}_{2} \mathrm{O}$. All four tremolites show very low halogen contents. They thus differ e.g. from some Central Swedish skarn tremolites (Geijer 1961), which contain appreciable amounts of fluorine (average $\mathrm{F}$ content of eight tremolites 0.7 percent). On the other hand, there are no indications of fluorine concentrations, e.g. in the form of humite minerals, in the vicinities of any of the four tremolites of the present study. The fluorine contents of the micas occurring in specimens 3 and 4 have not been determined.

\section{Density and optical properties}

Densities were determined with a pycnometer, using toluene as liquid. Two separate measurements were made of each sample to be analyzed chemically. The results and the averages of the two measurements are given in Table 1.

In thin section all four tremolites are colourless and clear. Microscopic examination by the immersion method reveals that the samples are optically not quite homogeneous. 


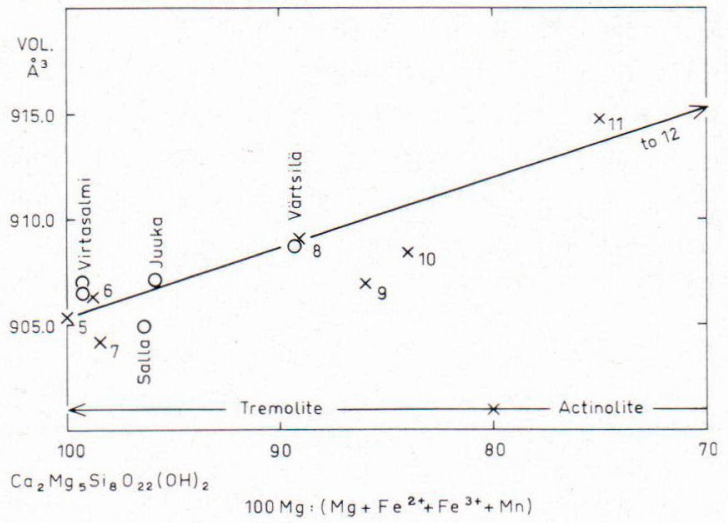

Fig. 2. The relation between chemical composition and unit cell volume of the four tremolites. The crosses numbered 5 through 12 represent plots of tremolites and actinolites collected from the literature:

5. Synthetic tremolite. Colville et al. 1966.

6. Tremolite. Zussman 1959.

7. Tremolite. Sample G-21. Gouverneur mining district, U.S.A. Ross et al. 1969.

8. Tremolite. Sample Varzo 7. Lepontine Alps, Switzerland. Wenk 1971.

9. Tremolite, Sample Vz 194, Lepontine Alps, Switzerland. Wenk, op.cit. ibid.

10. Tremolite, sample Varzo 6, Lepontine Alps, Switzerland. Wenk, op.cit. ibid.

11. Actinolite, Siilinjärvi, Finland. Puustinen 1972.

12. Synthetic ferroactinolite, not shown in the figure. Unit cell volume $938.7 \AA 3$. Ernst 1966 . A line has been drawn from the point of the synthetic tremolite (5) to that of the synthetic ferroactinolite (12).

The ranges of variation of the refractive indices have been expressed in Table 1. However, these ranges of variation are only slightly greater than the apparent accuracy of these measurements.

For each of the four tremolites two figures for both $2 \mathrm{~V} \alpha$ and $\mathrm{c} \wedge \mathrm{Z}$ have been given. These refer to measurements on two separate grains, respectively.

\section{X-ray Crystallography}

Powder patterns of the tremolites were run. As there are only small differences in the patterns between the four tremolites, only
Table 2. X-ray powder pattern of the tremolite from Kajoo, Juuka. Philips diffractometer, filtered Copper radiation with quartz standard.

\begin{tabular}{|c|c|c|c|}
\hline hkl & I & $\mathrm{d}_{\text {cale }}$ & $\mathrm{d}_{\text {obs }}$ \\
\hline 020 & 17 & 9.028 & 9.035 \\
\hline 110 & 40 & 8.416 & 8.411 \\
\hline 130 & 4 & 5.086 & 5.094 \\
\hline 111 & 1 & 4.881 & 4.884 \\
\hline 200 & 10 & 4.756 & 4.757 \\
\hline 040 & 8 & 4.514 & 4.513 \\
\hline 220 & 13 & 4.208 & 4.209 \\
\hline 131 & 1 & 3.8774 & 3.8776 \\
\hline $\left.\begin{array}{l}041 \\
131\end{array}\right\}$ & 6 & $\left\{\begin{array}{l}3.3822 \\
3.3810\end{array}\right\}$ & 3.3819 \\
\hline 240 & 23 & $\begin{array}{l}3.3610) \\
3.2742\end{array}$ & 3.2764 \\
\hline 310 & $>100$ & 3.1232 & 3.1239 \\
\hline 221 & 5 & 2.9389 & 2.9387 \\
\hline 330 & 14 & 2.8054 & 2.8045 \\
\hline$\overline{3} 31$ & 3 & 2.7322 & 2.7327 \\
\hline 151 & 9 & 2.7061 & 2.7051 \\
\hline$\underline{0} 61$ & 4 & 2.5927 & 2.5920 \\
\hline$\overline{2} 02$ & 3 & 2.5347 & 2.5338 \\
\hline 350 & 5 & 2.3827 & 2.3825 \\
\hline 351 & 9 & 2.3374 & 2.3388 \\
\hline$\overline{4} 21$ & 4 & 2.3219 & 2.3222 \\
\hline 420$\}$ & 2 & $\{2.2998\}$ & 2.2994 \\
\hline 171$\}$ & 2 & $\{2.2990\}$ & \\
\hline 261 & 4 & 2.1620 & $\begin{array}{l}2.1629 \\
.0435\end{array}$ \\
\hline 202 & 1 & 2.0434 & 2.0435 \\
\hline 351 & 3 & 2.0165 & 2.0163 \\
\hline 370 & 3 & 2.0010 & 2.0014 \\
\hline 190 & 1 & 1.9630 & 1.9635 \\
\hline 421 & 1 & 1.9268 & 1.9267 \\
\hline 510 & 12 & 1.8921 & 1.8926 \\
\hline $\left.\begin{array}{l}460 \\
191\end{array}\right\}$ & 1 & $\left\{\begin{array}{l}1.8659 \\
1.8655\end{array}\right\}$ & 1.8659 \\
\hline 530 & 10 & 1.8141 & 1.8138 \\
\hline 461 & 6 & 1.6496 & 1.6498 \\
\hline 480 & 4 & 1.6371 & 1.6374 \\
\hline 1.11 .0 & 2 & 1.6176 & 1.6177 \\
\hline 600 & 5 & 1.5855 & 1.5857 \\
\hline 153$\}$ & 3 & $\left\{\begin{array}{l}1.5785 \\
1.5789\end{array}\right\}$ & 1.5783 \\
\hline $\begin{array}{l}552 \\
620\end{array}$ & & $\begin{array}{l}(1.5782) \\
(1.5616)\end{array}$ & \\
\hline$\overline{1} .11 .1$ & 2 & 1.5616 & 1.5616 \\
\hline 2.10 .1$)$ & & $(1.5613)$ & \\
\hline$\overline{6} 02$ & 2 & 1.5332 & 1.5328 \\
\hline 0.12 .0 & 4 & 1.5047 & 1.5047 \\
\hline 4.10 .0$\}$ & 10 & $\{1.4381\}$ & 1.4382 \\
\hline
\end{tabular}

one, viz. that of Juuka, is reproduced in Table 2 .

The unit cell dimensions, deduced from the powder patterns, are listed in Table 1. In addition, the cell dimensions of the Virtasalmi tremolite, determined by Atso Vorma 
from single crystal precession photographs, are also listed in Table 1.

The unit cell dimensions of the four tremolites differ only a little from each other and are quite close to those given in the literature for the tremolites near the end members composition $\mathrm{Ca}_{2} \mathrm{Mg}_{5} \mathrm{Si}_{8} \mathrm{O}_{22}(\mathrm{OH})_{2} \quad$ (e.g. Colville et al. 1966; Zussman 1959; Papike et al. 1969 and Ross et al. 1969). However, there are small differences in the cell dimensions between the four tremolites. To illustrate the variations, the unit cell volumes have been plotted against the ratio $100 \mathrm{Mg}$ : $\left(\mathrm{Mg}+\mathrm{Fe}^{2+}+\mathrm{Fe}^{3+}+\mathrm{Mn}\right)$ in Figure 2. In the figure there are also shown the plots of six other tremolites, and one actinolite, collected from literature and an ascending line that has been drawn from the point of a synthetic tremolite, $\mathrm{Ca}_{2} \mathrm{Mg}_{5} \mathrm{Si}_{8} \mathrm{O}_{22}(\mathrm{OH})_{2}$ (Colville et al., op.cit.), to the point of a synthetic ferroactinolite, $\mathrm{Ca}_{2} \mathrm{Fe}_{5}{ }^{2+} \mathrm{Si}_{8} \mathrm{O}_{22}(\mathrm{OH})_{2}$ (Ernst 1966), not shown in the figure. The inclination of the line illustrates the effect of the replacement of $\mathrm{Mg}$ by $\mathrm{Fe}^{2+}$. The points of the Virtasalmi, Juuka and Värtsilä lie quite near the line, whereas the point of the Salla tremolite is slightly off. The deviation of the Salla tremolite can be explained to be caused partly by the inaccuracy of the measurements, partly by the effects of aluminum and ferric iron contents in the way as has been suggested e.g. by Wenk (1971).

Acknowledgments - Thanks are due to the following persons of the Geological Survey of Finland: to Dr. Raimo Lauerma and to Mr. Osmo Nykänen, Mag.Phil., for the specimens 3 and 4, respectively, to Prof. Maunu Härme for advice in collection of specimen 2, to Prof. Ahti Simonen and Dr. Atso Vorma for critical reading of the manuscript, to Mrs. Toini Mikkola, Lic.Phil., for some of the optical determinations, to Dr. Atso Vorma for determination of the unit cell parameters of the Virtasalmi tremolite by a single crystal study, to Mr. Pekka Kallio, Mag.Phil., and Mr. Matti Vaasjoki, Mag.Phil., for assistance in the calculation of the unit cell parameters, to Mrs. Lea Torssonen and Mrs. Anni Vuori for the drawing and to Mr. Reijo Niemelä for assistance in the field work.

The authors are also indebted to the firm $\mathrm{Pa}$ raisten Kalkkivuori Osakeyhtiö-Pargas Kalkbergs Aktiebolag for guidance in the Virtsalmi area.

\section{REFERENCES}

Aurola, Erkki (1960) The limestones and limestone quarries of Finland. Pp. 18-22 in "Nonmetallic mineral deposits, Finland», comp. by E. Aurola and K. J. Neuvonen. Intern. Geol. Congress, XXI Session, Norden 1960. Guide to excursions A 37, A 38, C 32, C 33 .

Colville, Patricia A., Ernst, W. G. and Gilbert, M. C. (1966) Relationships between cell parameters and chemical compositions of monoclinic amphiboles. Am. Miner. 51: 1727-1754.

Ernst, W. G. (1966) Synthesis and stability relations of ferrotremolite. Amer. J. Sci. 264: 3765.

Eskola, Pentti (1919) Limestones in Finland. Pp. 256-265 in "Suomen kalkkikivi», by P. Eskola, V. Hackman, A. Laitakari and W. W. Wilkman. Suomen geol. toimisto, Geotekn. Tied. 21.
Frosterus, Benj. and Wilkman, W. W. (1916) Beskrifning till bergsartskartan, D3, Joensuu. Résumé en Français. Geologisk Öfversiktskartan öfver Finland. 1:400 000. 89 p.

Geijer, Per (1961) The distribution of halogens in skarn amphiboles in Central Sweden. Arkiv. Min. Geol. 2 (36): 481-504.

Haapala, Paavo (1936) On serpentine rocks in Northern Karelia. Bull. Comm. Géol. Finlande 114: $65-66$.

Huhma, Aarto (1971) [Map of Pre-Quaternary rocks], 4311 Sivakkavaara. Geological Map of Finland, $1: 100000$.

Hyvärinen, Lauri (1969) On the geology of the copper ore field in the Virtasalmi area, eastern Finland. Bull. Comm. Géol. Finlande 240. 82 p. 
Lauerma, Raimo (1967) [Map of Pre-Quaternary rocks], 3643 Kursu. Geological Map of Finland, $1: 100000$.

Meriläinen, Kauko (1961) Albite diabases and albitites in Enontekiö and Kittilä, Finland. Bull. Comm. Géol. Finlande 195: 75 p.

Nuutilainen, Juhani (1968) On the geology of the Misi iron ore province, Northern Finland. Ann. Acad. Scient, Fennicae, Ser. A, III. Geol.Geogr. 96: 98 p.

Nykänen, Osmo (1967) [Map of Pre-Quaternary rocks], $4232+4234$ Tohmajärvi. Geological Map of Finland, 1:100 000 .

- (1968) Kallioperäkartan selitys. 4232-4234 Tohmajärvi. Summary: Explanation to the map of rocks. Suomen Geologinen Kartta, 1:100 000. $66 \mathrm{p}$.

Papike, J. J., Ross, Malcolm and Clark, Joan R. (1969) Crystal-chemical characterization of clinoamphiboles based on five new structure refinements. Mineral. Soc. Amer. Spec. Pap. 2: $117-136$.
Peltola, Esko (1960) On the black schists in the Outokumpu region in Eastern Finland. Bull. Comm. Géol. Finlande 192: 53-54.

Puustinen, Kauko (1972) Richterite and actinolite from the Silinjärvi carbonatite complex, Finland. Bull. Geol. Soc. Finland. 44: 83-86.

Ross, Malcolm; Papike, J. J. and Shaw, K. Wier (1969) Exsolution textures in amphiboles as indicators of subsolidus thermal histories. Miner. Soc. Amer. Spec. Pap. 2: 275-299.

Vähätalo, Veikko (1953) On the geology of the Outokumpu ore deposit in Finland. Bull. Comm. Géol. Finlande 164: 41-42.

Wenk, Hans-Rudolf (1971) Variations of lattice constants in clinoamphiboles. Zeitschr. Krist. 133: $341-363$.

Wiik, H. B. (1953) Composition and origin of soapstone: Bull. Comm. Géol. Finlande 165. $57 \mathrm{p}$.

Zussman, J., (1959) A re-examination of the structure of tremolite. Acta Cryst. 12: $309-312$.

Manuscript received, October 6, 1975. 